Seminário de Pesquisa

Programa de Pós-Graduação

Design FAU USP

\title{
Pesquisando capas de disco do rock brasileiro dos anos 1980: estratégias metodológicas para a coleta e a análise de dados
}

\author{
Paulo Eduardo Moretto, Priscila Lena Farias \\ estratégias metodológicas; análise visual; design gráfico; rock \\ brasileiro anos 1980; capas de disco
}

Numa década conturbada, o rock acabou por influenciar toda uma geração, tornando as capas de disco de vinil um artefato gráfico emblemático dos anos 1980. Após um panorama de reconhecimento, propõe-se o estudo das capas de disco do rock brasileiro desta década, em termos históricos, culturais, estéticos e de sua linguagem visual. Dada a impossibilidade de acesso ao Centro Cultural São Paulo, único acervo público com número significativo dessas

Curso

Doutorado

\section{Linha de Pesquisa}

Design: Processos e Linguagens

\section{Paulo Eduardo Moretto}

Doutorando do Programa de Pós-Graduação em Design da Universidade de São Paulo. Desde a graduação (1991) trabalhou como designer gráfico e curador. Para seu mestrado (2004), ele investigou cartazes brasileiros do século XX. Seu doutorado é financiado pela CAPES.

e-mail: pmoretto@usp.br Lattes: http://lattes.cnpq. br/9595290510004452

Orcid: https://orcid.org/0000-

0001-8393-6514

\section{Priscila Lena Farias}

Professora Associada e coordenadora do LabVisual Laboratório de Pesquisa em Design Visual na FAU USP. Autora de diversos artigos e livros sobre tipografia, semiótica e design.

Seus interesses atuais de pesquisa

são história da tipografia, e

letreiramento no espaço público.

e-mail: prifarias@usp.br

Lattes: http://lattes.cnpq.

br/7204930940034076

Orcid: http://orcid.org/0000-

0002-2540-770X peças gráficas na cidade, adotou-se, como primeira estratégia metodológica, o levantamento, na internet, de imagens das capas dos discos lançados no período. A organização de um acervo digital preliminar, com 83 capas, permitiu tabular os primeiros dados (títulos dos álbuns, bandas e anos de lançamento) e iniciar a análise visual. Posteriormente, para levantar dados complementares e aprofundar análises gráficas, foi organizado um acervo físico definitivo com 90 itens adquiridos em sebos e feiras especializadas. A análise visual preliminar identificou estruturas e elementos recorrentes e possibilitou a elaboração de critérios (ver figura) para seu aprofundamento, com base em princípios de composição (Lupton \& Phillips, 2008) e linguagem visual (Twyman, 1986), analisados a partir dos conceitos de "plural" e "singular" (Aragão, 2011), e de características do pós modernismo (Migliari, 2010) (Moretto \& Farias, 2020). Os dois acervos (digital e físico) foram complementares. 0 primeiro agilizou o início da pesquisa, permitindo a identificação de caminhos a seguir. O segundo, compilado com investimento de recursos financeiros e mais tempo, permitiu, através de acesso constante às peças gráficas, análises mais detalhadas. 


\begin{tabular}{|c|c|c|c|c|}
\hline \multirow{9}{*}{$\begin{array}{l}\text { Estrutura visual } \\
\text { (Plural, Plural com } \\
\text { variações, Singular) }\end{array}$} & \multirow{5}{*}{$\begin{array}{l}\text { Elementos } \\
\text { pictóricos }\end{array}$} & \multirow{3}{*}{ Fotografa } & Retrato da banda & Cenário \\
\hline & & & \multirow{2}{*}{ Outras fotos } & Contextual \\
\hline & & & & Associação \\
\hline & & \multirow[t]{2}{*}{ Ilustração } & \multicolumn{2}{|c|}{ Apropriação de imagens } \\
\hline & & & \multicolumn{2}{|l|}{ Imitação de estilos } \\
\hline & \multirow{4}{*}{ Elementos verbais } & \multirow{3}{*}{ Elemento verbal principal } & \multicolumn{2}{|c|}{ Nome da banda ou Título do álbum } \\
\hline & & & \multicolumn{2}{|c|}{ Fotocomposição, caracteres transferiveis, caligrafia ou letreiramento } \\
\hline & & & \multicolumn{2}{|c|}{ Caracteristicas pós-modernas } \\
\hline & & Elemento verbal secundário & \multicolumn{2}{|c|}{ Tratamento gráfico igual ao do elemento verbal principal (ou não) } \\
\hline
\end{tabular}

Tabela 1 Critérios para descrição das capas dos álbuns.

\section{Course}

Doctoral

\section{Line of Research}

Design: Processes and Languages

\section{Paulo Eduardo Moretto}

PhD candidate at the University of São Paulo Post Graduate Program in Design. Since graduation (1991) he has worked as a graphic designer and curator. For his Master's degree thesis (2004), he investigated 20th century Brazilian posters. His PhD research is supported by CAPES.

e-mail: pmoretto@usp.br

Lattes: http://lattes.cnpq. br/9595290510004452

Orcid: https://orcid.org/00000001-8393-6514

\section{Priscila Lena Farias}

Associate Professor and coordinator of LabVisual - the Visual Design Research Lab at FAU USP. Author of several articles and books on typography, semiotics and design. Her current research interests are the history of typography, and lettering in the public space.

e-mail: prifarias@usp.br

Lattes: http://lattes.cnpq. br/7204930940034076

Orcid: http://orcid.org/00000002-2540-770X

\section{Researching 1980s Brazilian rock album covers: methodological strategies for data collection and analysis}

\author{
Paulo Eduardo Moretto, Priscila Lena Farias
}

\section{methodological strategies; visual analysis; graphic design; 1980s brazilian rock; album covers}

In a troubled decade, rock ended up influencing a whole generation, turning vinyl album covers into emblematic graphic artefacts of the 1980s. Following a recognition survey, it is proposed a study on Brazilian rock album covers of this decade, through historical, cultural, aesthetic and visual language aspects. Given the impossibility of access to Centro Cultural São Paulo [São Paulo Cultural Center], the only public archive with a significant number of these graphic pieces in the city, as a first methodological strategy it was adopted the search on the internet for images of the albums released in the period. The organisation of a preliminary digital collection, with 83 covers, made it possible to tabulate a first set of data (album titles, bands and years of release) and to start a visual analysis. Subsequently, in order to collect complementary data and to deepen the graphic analysis, a definitive physical collection was organised with 90 items acquired in second hand stores and specialised fairs. The preliminary visual analysis identified recurring structures and elements, and enabled the elaboration of criteria (see figure) for further development, based on principles of visual composition (Lupton \& Phillips, 2008) and language (Twyman, 1986), analysed within the concepts of "plural" and "singular" (Aragão, 2011), and postmodern characteristics (Migliari, 2010) (Moretto $\&$ Farias, 2020). The two collections (digital and physical) were 
complementary. The first one allowed for agility in the beginning of the research, and also for the identification of the paths to be followed. The second one, which was compiled through investment of financial resources and extra time, allowing for more detailed analysis through constant access to the graphic piece.

\begin{tabular}{|c|c|c|c|c|}
\hline & & & & Neutral background \\
\hline & & & Band's portrait & Scenario \\
\hline & & Photograph & & Graphic interventions \\
\hline & Pictorial elements & & & Contextual \\
\hline & & & & Association \\
\hline & & & Collage & \\
\hline & & Illustration & Appropriation of & \\
\hline (Plural, Plural with & & & Style imitation & \\
\hline & & & Band's name or & \\
\hline & & & Position: top, ce & \\
\hline & & & Homogeneous & iet of characters \\
\hline & Verbal elements & & Upper, lower or & \\
\hline & & & Transferable or & acters, calligraphy or lettering \\
\hline & & & postmodern che & \\
\hline & & Secondary verbal element & Same graphic tr & ain verbal element (or not) \\
\hline
\end{tabular}

Table 1 Criteria for description of album covers.

\section{Referências | References}

ARAGÃO, I. 2011. O plural e o singular nas composições visuais dos rótulos de bebida. In: S. Campello \& I. Aragão (eds.). Imagens comerciais de Pernambuco: ensaios sobre os efêmeros da Guaianases: 93-113. Recife: Néctar.

LUPTON, E. \& PHILIPS, J. C. 2008. Graphic design the new basics. New York: Princeton Architectural.

MIGLIARI, M. de M. 2010. Tipografia pós-moderna nas Bienais da Associação dos Designers Gráficos: 1992-2009. Tese de Doutorado, Puc-Rio, Rio de Janeiro. MORETTO, P. \& FARIAS, P. L. 2020. 1980's Brazilian rock album covers: A visual analysis. In: VUKIC, F. \& KOSTESIC, I. (eds.). Lessons to Learn? Past Design Experiences and Contemporary Design Practices. Proceedings of the ICDHS 12th International Conference: 217-229. Zagreb: UPI2M Books.

TWYMAN, M. 1986. Articulating graphic language: a historical perspective. In: WROLSTAD, M. E. \& FISCHER, D. F. (orgs.). Toward a new understanding of literacy: 188-251. New York: Praeger. 